\title{
Can Tourism Business Development Cause Environmental Damage? A Perspective of Spatial Planning
}

\author{
I G B Suryawan, I P G Seputra, Indah Permatasari \\ Faculty of Law \\ Universitas Warmadewa \\ Denpasar-Bali, Indonesia \\ igustibagussuryawan@yahoo.com
}

\begin{abstract}
Tourism industry is closely related to the environment. In tourism industry, natural or environmental beauty is one of the attractions for tourists. In reality, however, the development of tourism not only provides positive impacts on the environment but also results in significant negative impacts. The purpose of this research is to determine the effect of tourism business development on environmental damage and to determine preventive efforts to prevent the occurrence of environmental damage. This research is an empirical law study. This research used primary data and secondary data. Data were collected through interview technique to three officers in three different government institutions. The sample was determined using non-probability/non-random sampling technique. The findings showed the development of the tourism industry absolutely has a direct impact on the environment. This can be seen from the tourism business that causes environmental damage either directly or indirectly to the physical, chemical and/or biological changes to the environment that exceed the standard criteria of environmental degradation. Preventive measures that can be taken to prevent environmental damage are through control and licensing system.
\end{abstract}

Keywords—tourism business; environment; spatial planning

\section{INTRODUCTION}

Tourism Industry is a highly-developed industry in Bali Province. Tourist visits annually undergo a significant increase. Increasing the development of tourism in the province of Bali, not only provide a positive impact, but also causes negative impacts, especially on the environment. Under the provisions of Article 1 Sub-Article 1 of Law Number 32 of 2009 Concerning Environmental Protection and Management, the environment is the unity of space with all objects, power, circumstances, and living things, including human beings and their behavior, which affect nature itself, the survival of the living fair, and the welfare of human beings and other living beings.

The development of tourism business that aims to support the needs of tourists is indubitably allowed. However, the problems arise when the development and development of tourism business are not accompanied or do not pay attention to the existing environment. Development of tourism businesses that do not pay attention to the environment are still found in Bali. In fact, the management and the tourism stakeholders have the responsibility to guarantee the safety, and of course the lives of tourists, and people living surrounding tourism destination, when risks and disaster risks occur in the destination [1].

By the development of tourism, the contradiction between tourists and environment is becoming more and more serious, which is mainly reflected in the rapid development of tourism industry and the lack of legislation on tourism environmental protection [2]. Investors or tourism entrepreneurs as tourism business providers with the intention to gain the maximum profits often make the development of tourism businesses such as hotels, restaurants and other supporting activities without regard to the environment. The development in the coastal border area and the cliff border is still found in Bali, which certainly can cause negative impact to the environment. This development trend is uncategorized into sustainable development. Spatial planning is needed and plays an important role in this case. Based on Article 1 number 5 of Law Number 26 of 2007, Spatial Planning is a system of spatial planning process, space utilization, and control of space utilization. So with the spatial arrangement is expected to minimize the occurrence of environmental damage due to the development of tourism. However, the reality is still encountered a tourism business that cause negative impacts to the environment. Based on the background, it can be drawn two problems, first is how the impact on the development of tourism business on environmental damage in Bali Province when viewed from the perspective of spatial planning and how preventive efforts can be done to overcome it.

\section{METHOD}

This research is an empirical law study. This research used primary data and secondary data. Data were collected through interview technique to three officers in three different government institutions. The sample was determined using non-probability/non-random sampling technique. 


\section{RESULT AND DISCUSSION}

A. Impact of Tourism Business Development on the Environmental Damage in Bali Province Viewed from Spatial Planning Perspective

The development of tourism business in Bali is rapidly growing. The tourism industry in Bali not only attracts tourists' attention but also tourism entrepreneurs/investors. The number of tourists in Bali each year has increased. This can be seen from the total tourists who visit to Bali. A total tourist arrival in 2012 to Bali is 2.892.019, whereas in 2016 the number of tourists soared to total visits 4.927.937 [3]. Bali Tourism Board statistic on March 2016 recorded the growth of tourist visitation to Bali $15.26 \%$ which increased compared to previous year that was only $6.25 \%$ [4]. The phenomenon of growth in tourist arrivals to Bali will certainly encourage an increased need or demand of tourists; one of them is from the accommodation sector [5]. In globalization era nowadays, tourism sector has become one of biggest and most powerful industry in world, and tourism is the biggest revenue sector especially in community economic life and country [6]. Based on Article 1 number 7 of Law Number 10 of 2009 on Tourism, what is meant by tourism business is a business that provides goods and /or services for meeting the needs of tourists and the implementation of tourism.

The emergence of tourism business is inseparable from the influence of tourism entrepreneurs. Tourism entrepreneurs who conduct business activities in Bali of course give a big influence on the sustainability of tourism and the environment. Not only tourism entrepreneurs, but the government and society also have a great influence as well. Tourism entrepreneurs as tourism business providers with the intention to gain the maximum profits often make the development of tourism businesses such as hotels, restaurants and other supporting activities without regard to the environment. Spatial arrangement is closely related to the environment as well as tourism. Based on Article 1 Number 5 of Law Number 26 of 2007, which is meant by Spatial Planning, is a system of spatial planning process, space utilization, and control of space utilization. Spatial planning is one of the instruments of environmental damage prevention. Development that is not concerned with the environment and not in accordance with the utilization of space, of course, can cause negative impact on the environment. Based on Article 1 number 14 of Law Number 26 of 2007, what is meant by the utilization of space is an effort to realize space structure and spatial pattern in accordance with the spatial plan through the preparation and implementation of the program and the financing.

Based on the results of interviews with officer government institutions can be seen that the existence of limited space is also one of the factors causing the violation of space utilization. The development of tourism facilities should be done by taking into account the layout, sustainability and environmental quality. However, still found the development of tourism businesses that do not pay attention to the environmental sustainability and quality. So that the development of tourism business in a space that is not in accordance with the utilization of course can cause damage to the environment. The development trend that is developed and found in Bali is the development that is done in the coastal border area as well as the cliff border that is the local protection area. This development trend is certainly not categorized into sustainable development. So of course this development trend can cause negative impact on the environment. Based on Article 1 Number 1 of Law Number 32 of 2009 Concerning Environmental Protection and Management, the environment is a unity of space with all objects, power, conditions, and living things, including humans and their behavior, which affect nature itself, life, and the welfare of human beings and other sentient beings.

Tourism Bali is well known for its culture and its natural beauty. So the attraction of natural beauty has the value of this sale that encourages the occurrence of violations both in the coastal border region and the ravine gulf. Tourism employers are flocked to provide tourism facilities that have high selling value by presenting the natural beauty that sometimes violates the use of space. The action is classified into environmental destruction. Based on Article 1 Number 16 of Law Number 32 of 2009 on Environmental Protection and Management, what is meant by the destruction of the environment is the act of a person causing direct or indirect changes to the physical, chemical, and/or biological nature of the environment so that it exceeds the criteria raw environmental damage. The destruction of the environment reflects the following elements which result in the decrease of the function of the environment to a certain extent, the result is that the function of the Environment is less or no longer in accordance with its designation, so that it is no longer able to support the survival of humans and/or other living beings and is caused by human activities [7]. In the Provincial Regulation of Bali No. 16 of 2009 on Spatial Planning in Bali Province, especially Article 44 , it can be seen that coastal border and border gulf are local protection areas. Based on the provisions in Bali Provincial Regulation, No. 16 of 2009 on Spatial Plans of Bali Province, it can be seen that the determination of the distance of the coastal boundary at a distance of at least 100 meters from the highest sea tide point on the land and the distance of the cliff that does not less than 11 meters is calculated from the edge of the cliff towards the plane which is the rule of law to be obeyed. So development in this area must be adjusted with the rules in force.

Damage to the environment is one aspect that should not be pursued. Based on article 1 point 17 of Law Number 32 of 2009 Concerning Environmental Protection and Management referred to as environmental damage are direct and/or indirect changes to the physical, chemical, and/or biological characteristics of the environment that exceed the standard criteria of environmental life damage. The impact of the development of tourism businesses that affect the damage to the environment can be measured through the standard criteria of environmental damage. Under the provisions of Article 1 point 15 , the definition of environmental damage criteria shall be the limits of changes in the physical, chemical, and or biological properties of the environment that can be tolerated by the environment in order to preserve its functions. It cannot be denied that the particular environment that presents the natural beauty is one tourist attraction for tourists. So that the coast and the border of the cliff that is part of the environment 
get a negative impact from the development of tourism business. The impact of tourism business development on environmental damage can be seen from the existence of damaged coastal environments and abrasion. The coastal border has important benefits for maintaining beach sustainability and sanctity, building safety, and availability of space for public traffic, as provided for in Article 1 point 44 of Bali Province Regulation No. 16 of 2009 Concerning the Spatial Planning of Bali Province. But in facts based on observations are still found hotels that violate coastal border, especially in Badung District.

Violation of space utilization associated with the construction of tourism facilities is a difficult problem to overcome. When associated with system theory of L.M Friedman and the theory of factors that influence law enforcement of Soerjono Soekanto can be seen that law enforcement problems can be caused by several factors that affect. When examined in terms of legal substance, it can be seen that there has been clear legal rules governing spatial, tourism and protection and environmental management both within the law, provincial regulations and municipal regulations. In addition, it can be seen in the view of juridical that there is already clear legal rules relating to the governance of coastal boundary and border ravine.

Based on Article 1 Number 22 of Law Number 27 of 2007 concerning the Management of Coastal Zone and Small Islands, the Coastal Border is the land along the edge that is proportional to the shape and physical condition of the beach, at least 100 (one hundred) meters from the highest tide point in the direction land. Determination of coastal border distance is also law substantially also regulated in the provincial and city/district regulations. The implementation of spatial planning coordination must take spatial governance as the basic point [8]. Relating to the substance of the law at a distance of at least 100 (one hundred) meters from the highest tide point in the land direction is indeed a debate, especially in terms of the preparation of Regional Regulation Badung No. 26 of 2013 Concerning Spatial Planning of Badung District. Rules concerning coastal border distance formed due to coastal border have important functions and benefits. So when viewed from the factor of legal substance can be seen that there has been a clear legal rules governing coastal border as well as border ravine.

The legal structure factors also play an important role in relation to environmental damage issues. Law enforcers and the government are not firm enough to overcome this problem. Tourism is indeed an industry that gives a big impact to the economy, especially the local revenue in Bali Province, but the environment in this case must also remain protected and not sacrificed.

\section{B. Preventive Efforts on Environmental Damage}

Tourism has a close relationship with the environment. The environment is one of the main attractions of tourist interest by tourists. So that tourism and environment cannot be separated. Environment for tourism refers to the spatial environment for tourists to place themselves in it such as scenic areas and spots; it could be divided into macro environment and micro environment; macro environment means the surrounding, and micro environment refers to the space in the surrounding [9]. Based on the provisions of Article 1 number 3 of Law Number 10 Year 2009, Tourism is a variety of tourism activities and supported by various facilities and services provided by the community, entrepreneurs, the Government and the Regional Government. Referring to the provisions of the above article it can be seen that the community, entrepreneurs, the Government, and the Regional Government are the parties related to tourism, especially in the Province of Bali. Developments of tourism support facilities of course must be coupled with the use of space in accordance with existing rules and remain concerned about the environment. So it is expected that the construction of tourism support facilities does not clash with spatial arrangement nor does it cause damage to the environment.

The development of tourism business will not only give positive impact but also give negative impact especially to environment. To overcome the negative impact of the development of tourism business on environmental damage is needed a preventive measure. Preventive measures that may be undertaken include the provision of compliance in the form of guidance, incentives, disincentives, awarding, and stipulation of environmental quality standards, licensing and implementation of light administrative sanctions for tourism activities that allegedly have an important impact on the environment [10]. Based on the explanation of Law Number 32 of 2009 on Environmental Protection and Management, it can be seen that preventive measures in the context of controlling environmental impacts need to be implemented by maximally utilizing the monitoring and licensing instruments, so that the monitoring and licensing instruments have a very important role. Licensing is an instrument that has an important role as a preventive measure to control the negative impact on environmental damage. Licensing has regulatory and control functions. With the existence of a good licensing system of course can minimize violations related to the use of space which exists. Based on Article 1 Number 36 of Law, Paragraph 32 of 2009 concerning Environmental Protection and Management, business license and/or activity is license issued by technical institution to conduct business and/or activity. So before the building especially associated with established tourism business must have permission in advance.

Licensing plays an important role that has regulating functions. As a governing function it is intended that existing licensing can be carried out in accordance with its designation. With the maximization of the implementation of this regulating function, the negative impact of the development of tourism business on the damage to the environment can be minimized. So that the government based on its authority only issued permits for activities and development in accordance with the rules of spatial use or existing spatial to create a sustainable tourism. Based on the explanation of Law Number 32 of 2009 concerning Environmental Protection and Management, it can be seen that in the case of pollution and environmental degradation has occurred, it is necessary repressive measures as effectiveness law enforcement, consequences, and consistent. There is still found violations who related to the utilization of space, especially the development of tourism business, it is 
shows that the existing law enforcement is still weakness. The commitment and firmness of the government to enforce the law and crack down on violations that have occurred in particular with regarding to coastline violations is absolutely necessary. The government holds a central role and as one of the determinants for environmental cultivation that occurs due to the development of tourism business can be minimized.

\section{CONCLUSION}

The development of tourism business will not only give positive impact but also negative impact to environmental damage. Environmental damages are caused by the existence of tourism businesses established in local protected areas that are inconsistent with the utilization of existing space resulting in direct and or indirect who changes to the physical, chemical, and or biological properties of the environment that exceed the standard of environmental degradation. Preventive measures that can be done to overcome the impact of the development of tourism business on environmental damage are to maximally utilize the monitoring and licensing instruments. In addition to preventive measures, repressive measures of effectiveness law enforcement, consequences, and consistent are also needed to solves the existing environmental damage.

\section{ACKNOWLEDGEMENT}

The author would like to thank all the parties who have helped and contributed in the writing of this article, both those who contribute in the form of funding and critical ideas. Hopefully this paper can be useful theoretically and practically for the addition and development of knowledge, especially in the field of legal science.

\section{REFERENCES}

[1] A. W. Tyawati, Tourists Safety of Coastal Tourism Revisited a study at Parangtritis Beach, District of Bantul, Yogyakarta Special Region, Published by Atlantis Press, Asia Tourism Forum 2016 - The 12th Biennial Conference of Hospitality and Tourism Industry in Asia (ATF16), 2016, p. 131- 137.

[2] J. Quan and Z. Zhang, The Study on Legal Issues Concerning China's Tourism Environmental Protection, Published by Atlantis Press, International Conference on Manufacturing Engineering and Intelligent Materials (ICMEIM 2017), 2017, p. 667.

[3] Denpasar Government Tourism Office, Directory of Denpasar Tourism, Bali, p. 15. 2016,

[4] N. M. E. Mahadewi and N. K. D. Irwanti, Image Bali as An Ergonomic Island Destination, Published by Atlantis Press, Asia Tourism Forum 2016 - The 12th Biennial Conference of Hospitality and Tourism Industry in Asia (ATF-16), p. 150. 2016.

[5] K. Wiweka and K. T. P. Arcana. The Impact of Tourist Accommodation Development Toward the Socio-Cultural Aspects in The Seminyak Village, District of Kuta, Regency of Badung, Bali The Local Community), Atlantis Press, Asia Tourism Forum 2016 The 12th Biennial Conference of Hospitality and Tourism Industry in Asia (ATF-16), p. 216-215. 2016.

[6] N. K. Bagiastuti and N. N. S. Astuti. The Role of Tourism Department and Regional Tourism Promotion Agency in Developing Community Based Tourism, Atlantis Press, Asia Tourism Forum 2016 The 12th Biennial Conference of Hospitality and Tourism Industry in Asia (ATF16), p. 380. 2016.

[7] I. B. W. Putra, Hukum Bisnis Pariwisata, PT Refika Aditama, Bandung, p. 167-168. 2003.

[8] W. Guangjun and Dong Wei, Research on The Method of Spatial Planning System Coordination. Atlantis Press, Asia Tourism Forum 2016-The 12th Biennial Conferences p. 284-289. 2016.

[9] X. Jia, Consideration of the role of tourism environmental protection on the sustainable development of Tourism, Published by Atlantis Press, Advances in Engineering Research, volume 163, p. 1643.

[10] I. B. W. Putra, Hukum Bisnis Pariwisata, PT Refika Aditama, Bandung, p.83. 2003. 